\title{
A formação afetiva e literária de José Saramago em As pequenas memórias
}

\author{
Berttoni Licarião*
}

\section{"Vivemos para dizer quem somos": apresentação}

As idiossincrasias do escritor português José Saramago não se restringem a aspectos puramente estilísticos. Figura eminentemente pública, convencido da impossibilidade de um escritor se comprometer apenas com seu texto e não com a sociedade em que vive, Saramago defendia que os leitores procuram em seus romances, mais do que uma história, o autor delas (ARIAS, 2003). Em inúmeras entrevistas deixou registrada sua compreensão de que, em seus romances, seria impossível dissociar autor e narrador, ou seja, que não há espaço algum entre sua figura de escritor e o texto a ser narrado que pudesse justificar o uso de semelhantes filtros narrativos. Para Saramago "toda obra literária leva uma pessoa dentro, que é o autor. $\mathrm{O}$ autor é um pequeno mundo entre outros pequenos mundos. A sua experiência existencial, os seus pensamentos, os seus sentimentos estão ali” (AgUiLERA, 2010, p. 224). Acerca do gênero no qual criou sua marca, Saramago é ainda mais claro:

\begin{abstract}
Tal como o entendo, o romance é uma máscara que esconde e, ao mesmo tempo, revela os traços do romancista. Com isso não pretendo sugerir ao leitor que se entregue durante a leitura a um trabalho de detective ou antropólogo, procurando pistas ou removendo camadas geológicas, ao cabo das quais [...] se encontraria escondido o autor. Muito pelo contrário: o autor está no livro todo, o autor é todo o livro, mesmo quando o livro não consiga ser todo o autor (SARAMAGO, 1997b, p. 40-41).
\end{abstract}

Assim, cada um de seus romances contém elementos que permitem ao seu leitor conhecer o homem por trás da obra. Não se deve concluir com isso, todavia, que aspectos biográficos transbordem em sua ficção. Como adverte o escritor, "se há um lugar onde eu estou é nos meus romances. Mas o leitor não deve perder o seu tempo a procurar a minha vida nos meus livros, porque ela não está ali. O que está ali não é a minha vida, mas a pessoa que sou, que é uma coisa

Doutorando em Literatura na Universidade de Brasília (UnB), Brasília, DF, Brasil. E-mail: berttoni@gmail.com 
muito diferente" (ARIAS, 2003, p. 30). A partir de seus livros, o leitor de Saramago é capaz de inferir uma visão de mundo própria de um homem de esquerda, alguém que vergalha aqueles em posição de poder e demonstra compaixão pelos pobres e oprimidos. Nesse sentido, é possível aproximar os comentários do autor acerca de sua obra às considerações de Paul de Man em "Autobiografia como desfiguração". Segundo este último, a autobiografia "não é um gênero ou um modo, mas uma figura de leitura ou de entendimento que ocorre, em algum grau, em todos os textos" (De Man, 2012, p. 4). Saramago carrega este princípio em cada uma de suas obras, como se buscasse exercitar na literatura sua própria máxima "vivemos para dizer quem somos":

O que eu quero é que cada leitor, pelos livros que escrevo, tenham uma boa ideia da pessoa que os escreve. Se eu quisesse e pudesse dizer quem sou, escreveria um livro para dizê-lo e talvez me enganasse [...]. Ou, pior ainda, poderia enganar os demais, pois, quando alguém se preocupa em dizer quem é, preocupa-se em mostrar o melhor de si e resiste a dizer que talvez seja um canalha, ninguém faz isso. [...] Não tenho nada a mais a dizer aos leitores além da compreensão que extraíram de quem eu sou a partir da leitura de meus livros. Não posso dizer que haja algo que eu gostaria de acrescentar porque, se o dissesse, significaria que isso falta nos livros que escrevi, e, se falta, por alguma razão há de ser (ARIAS, 2003, p. 28-29).

É curioso, todavia, que aos 83 anos de idade e em meio a um período de intensa produção, ${ }^{1} \mathrm{o}$ autor, que alegava se apresentar inteiro em cada um de seus romances, decida concluir um projeto de autobiografia engavetado há mais de vinte anos. A "ambiciosa ideia inicial", surgida por volta de 1982 quando José Saramago trabalhava em seu Memorial do convento, tinha por título O livro das tentações ${ }^{2}$ e pretendia "mostrar que a santidade, essa manifestação 'teratológica' do espírito humano capaz de subverter a nossa permanente e pelos vistos indestrutível animalidade, perturba a natureza, confunde-a, desorienta-a" (SARAMAGO, 2006a, p. 32). O autor reconhece, no entanto, que seus dotes literários estavam muito aquém do projeto original e acabou por convertê-lo num repositório das "memórias pequenas de quando fui pequeno, simplesmente" (SARAMAgo, 2006a, p. 34). Com As pequenas memórias, publicado em 2006, Saramago deixa o campo do romance por um instante para reelaborar as lembranças de sua infância em uma narrativa não-linear composta essencialmente por fragmentos, onde "cada momento é um momento em si”, e o "tempo pode andar para trás ou para a frente" (SARAMAGO, 2006b).

\footnotetext{
A caverna (romance, 2000), O homem duplicado (romance, 2002), Ensaio sobre a lucidez (romance, 2004), Don Giovanni ou o dissoluto absolvido (teatro, 2005), As intermitências da morte (romance, 2005), As pequenas memórias (autobiografia, 2006), A viagem do elefante (conto, 2008), Caim (romance, 2009).

2 O título faz referência à pintura As tentações de Santo Antão (c. 1500), do holandês Hyeronimus Bosch. O autor buscava criar paralelos entre as recordações de sua infância e os elementos alegóricos da pintura.
} 
As razões para a escolha da infância como matéria de sua biografia também merecem atenção crítica. Segundo o autor, não lhe importava escrever sobre a idade adulta, uma vez que a mesma já se encontra expressa em seus romances:

As autobiografias geralmente são relatos sobre a vida adulta, mas a mim interessa-me reconstituir pela memória o mundo daqueles anos e a criança que nesses anos cresceu. Digo às vezes que não concebo nada tão magnífico e exemplar como irmos pela vida levando pela mão a criança que fomos, imaginar que cada um de nós teria de ser sempre dois, que fôssemos dois pela rua, tomando decisões, dois diante das diversas circunstâncias que nos rodeiam e nos provocam. Todos iríamos pela mão de um ser de sete ou oito anos, nós mesmos, que nos observaria o tempo todo e a quem não poderíamos defraudar (SARAMAGO, 2013, p. 37).

Com efeito, As pequenas memórias apresentam seu tempo de germinação como ser humano até o início da adolescência, por volta dos 14 anos. Sua recusa em tratar da vida adulta, exposta em vários escritos anteriores à publicação da obra, ${ }^{3}$ será o fio condutor à questão-problema da presente análise. Em 1997, José Saramago encerrou o colóquio Dialogo sulla cultura portoghese realizado na Universidade de Turim, com uma conferência intitulada "A Estátua e a Pedra". Instrumento imprescindível aos interessados na obra saramaguiana, o texto consiste em uma explicação do autor por si mesmo na qual indica suas filiações literárias, o processo de produção de seus romances e, mais importante, a apresentação de dois conceitoschave à leitura de sua obra, dividida pelo próprio Saramago entre "fase da estátua" e "fase da pedra". É tempo de transcrever as palavras do escritor:

É como se desde o Manual de pintura e caligrafia até o Evangelho segundo fesus Cristo, durante catorze anos, me tivesse dedicado a descrever uma estátua. O que é a estátua? A estátua é a superfície da pedra, o resultado de tirar pedra da pedra. Descrever a estátua, o rosto, o gesto, as roupagens, a figura, é descrever o exterior da pedra, e essa descrição, metaforicamente, é o que encontramos nos romances que me referi até agora. Quando terminei $O$ Evangelho ainda não sabia que até então tinha andado a descrever estátuas. Tive de entender o novo mundo que se me apresentava ao abandonar a superfície da pedra e passar para seu interior, e isso aconteceu com Ensaio sobre a cegueira. Percebi, então, que alguma coisa tinha terminada na minha vida de escritor e que algo diferente estava a começar (SARAMAGO, 2013, p. 33-34).

A segunda fase dos romances de Saramago, iniciada com Ensaio sobre a cegueira, caracteriza-se por um retorno ao essencial, uma tentativa de "penetrar mais profundamente na pedra obscura do ser do que até então tinha sido capaz."

3 Referências à composição de As pequenas memórias podem ser encontradas em três entradas dos Cadernos de Lanzarote, além de outras menções em entrevistas, crônicas e conferências. 
(SARAMAGO, 2013, p. 39). Nela, o ser humano torna-se prioridade absoluta, preocupação íntima e matéria obsessiva de seu trabalho. É sintomático, portanto, que o projeto de autobiografia que se tornaria As pequenas memórias concretize-se em meio a uma nova fase de sua escrita, marcada por uma literatura que se dirige ao interior da pedra, ao poder taumatúrgico da palavra, capaz de manter vivos indefinidamente seus avós e a criança que foi. Qual seria, então, para retornarmos à questão-problema em formação, a relação entre as declarações em que José Saramago afirma estar presente em seus romances (ainda que traços biográficos sejam raros) e a elaboração de sua infância em uma autobiografia? Ou seja, uma vez que filiamos As pequenas memórias à "fase da pedra", na qual o autor se debruça sobre a essência do humano, qual a contribuição deste exercício memorialístico dentro de uma obra ficcional já considerada e defendida pelo autor como expressão de si mesmo?

\section{"Vivemos aqui, mas habitamos uma memória": a formação afetiva do escritor}

Contrariando as expectativas do gênero, ${ }^{4}$ Saramago dedica o início de suas memórias à reconstrução da aldeia em que nasceu, Azinhaga, localizada no concelho da Golegã, distante cerca de $100 \mathrm{~km}$ da capital Lisboa. As informações ali organizadas se empenham em apresentar características geográficas da região - "as fronteiras rumorosas de água e de verdes" (SARAMAGO, 2006a, p. 11) - e a relação da gente lá nascida com os elementos "que acabaram por lhe configurar o caráter" (SARAmAGO, 2006a, p. 10): os rios e as oliveiras. Ainda que sua família tenha se mudado para Lisboa apenas dois anos após seu nascimento, o autor insiste que naqueles primeiros anos de vida já se estabelecera a relação telúrica que determinaria seu retorno à terra ${ }^{5}$ no momento em que nasceria de novo, desta vez como autor:

Sem que ninguém de tal se tivesse apercebido, a criança já havia estendido gavinhas e raízes, a frágil semente que então eu era havia tido tempo de pisar o barro do chão com os seus minúsculos e mal seguros pés, para receber dele, indelevelmente, a marca original da terra (SARAMAgo, 2006a, p. 10).

Não por acaso, a ocorrência de "marca original" ainda no primeiro parágrafo da obra determinará o tom de uma autobiografia voltada à reflexão sobre aquilo que nos faz ser quem somos. A partir dele, o autor parecerá empenhado em exaurir as metáforas que remetem a "origem", tomando emprestadas as imagens de

4 Philippe Lejeune (1994) e François Dosse (2009) apontam o nascimento como ponto de partida mais comum em autobiografias e biografias.

5 Saramago retornará à Azinhaga na década de 1970 para colher depoimentos e notas que o ajudariam a compor o romance Levantado do chão. Será após a publicação deste romance em 1980 que o autor reconhecerá que "nasceu" como escritor de fato (REIS, 1998, p. 43-44). 
"gavinhas e raízes" como no trecho mencionado, ou ainda ao comparar sua aldeia ao "berço onde se completou sua gestação", como se fora uma "bolsa onde o pequeno marsupial se recolheu para fazer sua pessoa" (SARAMAGO, 2006a, p. 11, grifo nosso). Noutro momento, a casa dos avós maternos será referida como um "casulo mágico" onde "se geraram metamorfoses decisivas da criança e do adolescente" (SARAMAGO, 2006a, p. 15-16).

A busca pela constituição de uma essência é precisamente aquilo que, via de regra, encontramos em autobiografias. Philippe Lejeune, que estuda o gênero sob a perspectiva da leitura e recepção crítica da escrita, define autobiografia como toda "narrativa retrospectiva em prosa que uma pessoa real faz de sua própria existência, quando focaliza sua história individual, em particular a história de sua personalidade" (2014, p. 14, grifo nosso). De acordo com o teórico francês, todo projeto autobiográfico visa aproximar o leitor da "verdade pessoal, individual, íntima, do autor" através de um "pacto autobiográfico" que consiste na tentativa por parte do autor de contar sua vida (ou parte dela) imbuído de um "espírito de verdade" em "comunicação direta com o leitor" (LeJEune, 2014, p. 28).

O filósofo francês Georges Gusdorf também se debruçou sobre o gênero em questão, e contribui com uma perspectiva em certo sentido complementar à de Lejeune, uma vez que focada nos princípios constitutivos da produção do texto. Para Gusdorf (1991, p. 11), consiste a autobiografia no encontro do homem com sua imagem, "Um outro eu-mesmo, um duplo do meu ser" (1991, p. 11, tradução nossa), que está longe de advir de uma simples recuperação do passado tal como foi. Da mesma forma que a biografia para François Dosse (2009), o resultado desse encontro é, para Gusdorf, a criação de uma nova imagem, frágil e vulnerável, é verdade, mas depositária de uma expressão mais coesa do ser porque capaz de exprimir coerentemente o próprio destino:

O autor de uma autobiografia se impõe como tarefa contar sua própria história: trata-se, para ele, de reunir os elementos dispersos de sua vida pessoal e agrupá-los em um esquema de conjunto. O historiador de si mesmo desejaria desenhar seu próprio retrato, mas, assim como o pintor capta apenas um momento de sua aparência exterior, o autor de uma autobiografia consegue firmar todo seu destino em uma expressão coerente e total (GuSDORF, 1991, p. 28, tradução nossa).

Nesse sentido, à maneira daquele Casmurro ${ }^{6}$ que buscava unir as duas pontas da vida, as memórias pequenas de José Saramago se mantêm em tensão constante entre a recordação dos fatos e a busca por relacioná-lo aos elementos que formaram o homem e, consequentemente, o escritor. O trecho a seguir é bastante elucidativo desse mecanismo de autognose, quando episódios corriqueiros de pescaria adquirem ares transcendentais:

\footnotetext{
${ }^{6}$ Narrador do romance Dom Casmurro (1899), de Machado de Assis.
} 
Nunca fui grande pescador. [...] Como consequência, as minhas capturas sempre se reduziram a uns poucos pampos, barbos uma raridade e pequenos, e muitas horas passadas em vão (em vão, a bem dizer, nenhuma, porque, sem que me desse conta, ia "pescando" coisas que no futuro não viriam a ser menos importantes para mim, imagens, cheiros, rumores, aragens, sensações) (SARAMAgo, 20o6a, p. 76).

Convém trazer à tona as palavras de Gaston Bachelard acerca dos devaneios voltados à infância que trataremos em detalhes na próxima seção. De acordo com o filósofo e poeta francês "o inverno, o outono, o sol, o rio de verão são raízes de estações totais. Não são apenas espetáculos pela vista, são valores da alma, valores psicológicos diretos, imóveis, indestrutíveis. Vividos na memória, são sempre benéficos" (BACHELARD, 1988, p. 111).

Nas passagens acima e ao longo de As pequenas memórias, o esforço de José Saramago se volta à reconstrução consciente de um percurso, já apontado como não linear, que se relaciona teluricamente com a formação da identidade do adulto que escreve, sobretudo no desenvolvimento de sua sensibilidade aos fenômenos da natureza e na importância dos avós maternos, considerados seus "primeiros modelos éticos e literários" (REIs, 1998, p. 43). Jerônimo e Josefa, os referidos avós, a quem o escritor dedicou páginas e mais páginas de suas crônicas e sobre os quais discursou na cerimônia de aceitação do prêmio Nobel de Literatura em 1998, ${ }^{7}$ explicam, para Saramago, de onde vem e de que materiais se fez a pessoa que começou por ser e aquela que pouco a pouco vinha se tornando:

Ao pintar os meus pais e os meus avós com tintas de literatura, transformando-os, de simples pessoas de carne e osso que haviam sido, em personagens novamente e de outro modo construtoras da minha vida, estava, sem o perceber, a traçar o caminho por onde as personagens que viesse a inventar, as outras, as efectivamente literárias, iriam fabricar e trazer-me os materiais e as ferramentas que, finalmente, no bom e no menos bom, no ganho e no perdido, naquilo que é defeito mas também naquilo que é excesso, acabariam por fazer de mim a pessoa em que hoje me reconheço (SARAmago, 2012, p. 10).

As pequenas memórias apresentam-se, desse modo, como a oportunidade de reconstruir esses espaços e fazer reviver essas pessoas a quem o autor deve tanto de si, um resgate no qual a melancolia é suplantada pela resiliência, a ausência

7 O discurso tem por título De como a personagem foi mestre e o escritor seu aprendiz e começa da seguinte maneira: "O homem mais sábio que conheci em toda a minha vida não sabia ler nem escrever. Às quatro da madrugada, quando a promessa de um novo dia ainda vinha em terras de França, levantava-se da enxerga e saía para o campo, levando ao pasto a meia dúzia de porcas de cuja fertilidade se alimentavam ele e a mulher. Viviam desta escassez os meus avós maternos, da pequena criação de porcos que, depois do desmame, eram vendidos aos vizinhos da aldeia. Azinhaga de seu nome, na província do Ribatejo. Chamavam-se Jerónimo Melrinho e Josefa Caixinha esses avós, e eram analfabetos um e outro" (SARAmAGO, 2012, p. 7). 
é preenchida pela memória e a brutalidade compensada pela ternura. Diferentemente do que acontecerá com as cenas de sua vida de privações em Lisboa, marcadas por imprecisões temporais e secura de tom, ${ }^{8}$ as recordações envolvendo a "pobríssima morada" de Azinhaga são preenchidas com cores e detalhes marcantes, a exemplo do trecho que segue:

O espelho fazia parte de um pequeno e tosco toucador, também sem pintura, com uma gaveta central e duas gavetinhas aos lados, cheias de miudezas que não serviam para nada e que iam passando de um ano para o outro sem mudanças visíveis de conteúdo. Por cima da mesa, na parede branca, como uma galáxia de rostos, era onde se reuniam os retratos da família: a ninguém lhe ocorreu distribuí-los, como uma decoração, pelas paredes caiadas da casa-de-fora. Estavam ali como santos num altar, como peças de um relicário colectivo, fixos, imutáveis. A cozinha era o mundo. Havia duas camas, uma mesa que bamboleava no chão irregular e que de cada vez era preciso calçar para que não bandeasse, duas cadeiras pintadas de azul, a lareira com a "boneca do lar" ao fundo, uma figura vagamente antropomórfica, de contorno sumário, que desapareceu, como todo o resto (SARAMAGO, 2006a, p. 84-85).

Em se tratando de uma casa desaparecida há mais de 40 anos, a riqueza de detalhes impressiona. Não obstante, o próprio autor reconhece que a legitimidade de tantos pormenores pode ser posta em dúvida uma vez que "levamos dentro de nós o nosso pequenino mundo que, por sua vez, tem a ver com a memória de um mundo mais ou menos idílico que fabricamos ao nosso gosto" (ARIAS, 2003, p. 39). Com efeito, segundo George Gusdorf (1991, p. 13), ao evocar seus primeiros anos de vida, o escritor explora um domínio encantado que pertence somente a ele mesmo. É evidente que semelhante imposição da memória afetiva, longe de representar uma quebra do pacto autobiográfico, endossa a leitura dos fatos narrados sob a perspectiva de seu valor sentimental. A memória que Saramago apresenta em sua biografia se distancia, portanto, da mera reconstrução e surge como uma memória a ser habitada pelo escritor, vontade já expressa em entrevista a Juan Arias em 2002: "vivemos num lugar que pode ser como a aldeia em que nasci, mas no fundo habitamos uma memória" (ArIAs, 2003, p. 37). À medida que (re)escreve9

\footnotetext{
8 Note-se que as passagens em que o escritor questiona sua memória ou atribui as lembranças a outras pessoas são muito mais frequentes quando escreve sobre seus anos em Lisboa: "É-me difícil [...] situar certos acontecimentos no tempo" (SARAmago, 20o6a, p. 40), "Se a memória não me falha" (SARAMAGO, 2006a, p. 48), "Às vezes pergunto-me se certas recordações são realmente minhas" (SARAMAGo, 2006a, p. 58), "Dessa breve viagem [...] não guardo mais viva lembrança" (SARAmAGO, 2006a, p. 71). Já sobre a casa dos avós, escreve o autor com abundância de detalhes e amiúde atribui a essas lembranças um sentido de perenidade: "Ainda tenho no nariz o cheiro daquele barro molhado e nos olhos a cor vermelha do chão que empalidecia pouco a pouco" (SARAmago, 2006a, p. 84).

9 Muitos dos casos narrados em As pequenas memórias podem ser encontrados em textos anteriores à autobiografia, como em crônicas, diários, entrevistas e discursos. A história do acréscimo da alcunha "Saramago" ao nome da família, só para citar um exemplo, está presente no livro de crônicas "A bagagem do viajante" e nos diários "Cadernos de Lanzarote".
} 
sua história, Saramago se permite demorar-se um pouco a reavivar os sentidos pela lembrança, ao mesmo tempo que resgata a lembrança por meio dos sentidos:

pelo poder reconstrutor da memória, posso levantar em cada instante as suas paredes brancas, plantar a oliveira que dava sombra à entrada, abrir e fechar o postigo da porta e a cancela do quintal onde um dia vi uma pequena cobra enroscada, entrar nas pocilgas para ver mamar os bácoros, ir à cozinha e deitar do cântaro para o púcaro de esmalte esborcelado a água que pela milésima vez me matará a sede daquele Verão (SARAMAgO, 2006a, p. 16).

O destaque ao verão no trecho acima nos permite compreender, com a ajuda de Bachelard (1988, p. 111), de que maneira "a estação constitui a marca fundamental das lembranças”. Amiúde, as imagens da infância se tornam imagens grandes, engrandecidas e engrandecedoras, porque se associam ao universo de uma estação "que se pode chamar de estação total, que repousa na imobilidade da perfeição" (BACHELARD, 1988, p. 111). Não é difícil encontrar no edifício narrativo das memórias de José Saramago trechos como a passagem acima, nos quais a reconstrução idílica de suas reminiscências emparelha-se com marcadores temporais na fixação de uma lembrança imortalizada e transcendente, vestígios de um "mundo com suas cores primeiras, suas cores verdadeiras" (BACHELARD, 1988, p. 112). Ademais, parece clara a intenção de manter viva a aldeia da infância pelo poder taumatúrgico da palavra, assim como as pessoas que foram seus avós maternos. Ao apresentar ao grande público detalhes e episódios da vida desses dois camponeses analfabetos, Saramago não apenas os imortaliza na literatura, mas declara os fundamentos de sua formação moral na linhagem humilde daqueles avós que, de outra maneira, estariam perdidos sob uma espessa camada de anonimato:

É um homem como tantos outros nesta terra, neste mundo, talvez um Einstein esmagado sob uma montanha de impossíveis, um filósofo, um grande escritor analfabeto. Alguma coisa seria que não pôde ser nunca. Recordo aquelas noites mornas de Verão, quando dormíamos debaixo da figueira grande, ouço-o falar da vida que teve, da Estrada de Santiago que sobre as nossas cabeças resplandecia, do gado que criava, das histórias e lendas da sua infância distante. Adormecíamos tarde, bem enrolados nas mantas por causa do fresco da madrugada. Mas a imagem que não me larga nesta hora de melancolia é a do velho que avança sob a chuva, obstinado, silencioso, como quem cumpre um destino que nada poderá modificar. A não ser a morte. Este velho, que quase toco com a mão, não sabe como irá morrer. Ainda não sabe que poucos dias antes do seu último dia terá o pressentimento de que o fim chegou, e irá, de árvore em árvore do seu quintal, abraçar os troncos, despedir-se deles, das sombras amigas, dos frutos que não voltará a comer (SARAMAGO, 2006a, p. 119-120).

Tu estavas, avó, sentada na soleira da tua porta, aberta para a noite estrelada e imensa, para o céu de que nada sabias e por onde nunca viajarias, 
para o silêncio dos campos e das árvores assombradas, e disseste, com a serenidade dos teus noventa anos e o fogo de uma adolescência nunca perdida: "O mundo é tão bonito e eu tenho tanta pena de morrer." Assim mesmo. Eu estava lá (SARAmAgo, 2006a, p. 120).

Os trechos acima, dedicados a Jerônimo e Josefa, expõem a parcela humana de sua formação espiritual, de maneira análoga aos rios e córregos, às estradas de terra batida, aos bácoros e peixes, às sombras das oliveiras, às faias e choupos que compõem a moldura natural desse período de germinação com o qual o autor explicitamente relaciona sua infância.

\section{"Deixa-te levar pela criança que foste": o autor aprendiz}

À primeira vista, a última reminiscência de As pequenas memórias causará estranheza ao leitor de Saramago acostumado aos remates de seus romances. Todavia, caso não se dê por vencido e insista em ler nas entrelinhas, o mesmo leitor será recompensado com uma das chaves interpretativas da obra. Consiste essa passagem na recordação de uma cena em que Zezito surpreende um casal saindo às escondidas das ruínas de uma espécie de curral de porcos. Vejamos o trecho em questão para análise:

A pouca distância do quintal dos meus avós havia umas ruínas. [...] Um dia, devia andar pelos meus dezasseis anos, dou com uma mulher lá dentro, de pé, entre a vegetação, compondo as saias, e um homem a abotoar as calças. Virei a cara, segui adiante e fui sentar-me num valado da estrada, a distância, perto de uma oliveira ao pé da qual, dias antes, tinha visto um grande lagarto verde. Passados uns minutos vejo a mulher a atravessar o olival em frente. Quase corria. O homem saiu das ruínas, veio para mim (devia ser um tractorista de passagem pela terra, contratado para algum trabalho especial) e sentou-se ao meu lado. "Mulher asseada", disse. Não respondi. A mulher aparecia e desaparecia entre os troncos das oliveiras, cada vez mais longe. "Disse que você a conhece e que vai avisar o marido." Tornei a não responder. O homem acendeu um cigarro, soltou duas baforadas, depois deixou-se escorregar do valado e despediu-se: "Adeus." Eu disse: "Adeus." A mulher tinha desaparecido de vez. Nunca mais tornei a ver o lagarto verde (SARAMAgO, 2006a, p. 137-138).

A cena descrita não é a primeira passagem envolvendo sexualidade. $\mathrm{O}$ autor já descrevera as brincadeiras "de exploração táctil" debaixo das cobertas com a prima (SARAMAGO, 2006a, p. 39), a cena que considera o primeiro capítulo de sua educação sexual, quando encontra sua tia Emília bêbada a se masturbar no chão do quarto (SARAmAGO, 2006a, p. 106), seu namoro com a jovem Deolinda Bacalhau (SARAmAGO, 2006a, p. 42), ou ainda os acessos de ciúmes de um tio que o forçara a dar sua palavra de honra em defesa da honestidade da tia Maria Elvira. Tampouco 
devemos compreender a cena como a última de suas recordações em Azinhaga, uma vez que já completara 16 anos e passaria a "visitar a casa dos avós maternos com frequência cada vez menor" (SiLva, 2009, p. 54). O que subjaz ao trecho acima é a descrição de um rito de passagem, ativado literariamente por meio da imagem do lagarto verde. Essa relação metafórica pode ser melhor compreendida quando recorremos às palavras de Bachelard sobre a relação entre imagem e infância:

Habitamos melhor o mundo quando o habitamos como a criança solitária habita as imagens. Nos devaneios da criança, a imagem prevalece acima de tudo. As experiências só vêm depois. Elas vão a contravento de todos os devaneios de alçar vôo. A criança enxerga grande, a criança enxerga belo. O devaneio voltado para a infância nos restitui à beleza das primeiras imagens (1988, p. 97).

O lagarto verde pode ser entendido, portanto, como um ponto de transição entre o mundo da criança, vivido em constante maravilhamento com seus entornos, e a realidade desencantada da vida adulta. É sintomático que, uma vez perdida a inocência da criança frente ao flagrante adultério da mulher e a impudência do tratorista, o autor declare-se incapaz de reencontrar o lagarto, como se a partir daquele instante a infância fosse deixada para trás, junto com a ingenuidade que lhe é inerente. Corrobora com esta leitura o fato de que a própria elaboração da percepção, segundo José Saramago, pertence muito mais à esfera do cognoscível do adulto do que à da criança. Esta, via de regra, vive a paisagem, em oposição à atitude do homem, que a vê e avalia:

A criança que fui não viu a paisagem tal como o adulto em que se tornou seria tentado a imaginá-la a sua altura de homem. A criança, durante o tempo em que o foi, estava simplesmente na paisagem, fazia parte dela, não a interrogava, não dizia nem pensava, por estas ou outras palavras: "Que bela paisagem, que magnífico panorama, que deslumbrante ponto de vista!” (SARAmago, 20o6a, p. 13).

O maravilhamento, a propósito, também é um traço intrínseco à infância. Para Gaston Bachelard, se considerarmos os primeiros anos de vida como a soma das insignificâncias do ser humano, a infância adquire um significado fenomenológico próprio, "um significado fenomenológico puro porque está sob o signo do maravilhamento". Nesse sentido, Zezito se torna "o puro e simples sujeito do verbo maravilhar-se" (BACHELARD, 1988, p. 122) ao protagonizar umas quantas passagens através das quais se estabelece, no campo fértil da solidão, ${ }^{10}$ a permanência do nú-

10 De acordo com Bachelard, "Quando sonhava em sua solidão, a criança conhecia uma existência sem limites. Seu devaneio não era simplesmente um devaneio de fuga. Era um devaneio de alçar vôo" (1988, p. 94). Em nota similar, Saramago reconhece que a solidão é uma espécie de refúgio tanto para o homem que se tornou como para a criança que foi, e recorda que até os catorze ou quinze anos, "não gostava de estar com os meninos da minha idade, gostava mesmo era de passear pelo campo, pelo rio, pelas colinas de lá, sozinho” (ARIAs, 2003, p. 34). 
cleo fenomenológico que acompanhará para sempre o adulto, a exemplo do trecho: "quando despertei, na primeira claridade da manhã, e saí, esfregando os olhos, para a neblina luminosa que mal deixava ver os campos ao redor, senti dentro de mim, se bem recordo, se não o estou a inventar agora, que tinha, finalmente, acabado de nascer" (SARAMAgo, 2006a, p. 20). Ainda de acordo com Bachelard, ao "aprofundarmos nosso devaneio na direção da infância, enraizamos mais profundamente a árvore do nosso destino. Permanece aberto o problema de saber onde o destino do homem tem suas raízes verdadeiras" (BACHELARD, 1988, p. 131).

Vimos, noutras palavras, que a busca empreendida por José Saramago durante a segunda fase de produção de seus romances tem como alvo precisamente responder àquele elementar quem somos. Ao tentarmos ler As pequenas memórias como uma maneira encontrada pelo autor de completar a apresentação de si mesmo por sua obra, é possível entrever outra possibilidade interpretativa: a da criança que escreve o adulto, ou ainda, formulada noutros termos, a ideia de um autor escrito desde sempre pela criança que foi. Se considerarmos os acontecimentos narrados pelo escritor português como consolidadores do enraizamento do adulto à criança, estaremos, inevitavelmente, aproximando uma vez mais Saramago e Bachelard, que escreve:

Ao meditar sobre a criança que fomos, para além de toda a história de família, após haver ultrapassado a zona dos pesares, após haver dispersado todas as miragens da nostalgia, atingimos uma infância anônima, puro foco de vida, vida primeira, vida humana primeira. E essa vida está em nós - sublinhemo-lo ainda uma vez -, permanece em nós (BACHELARD, 1988, p. 120).

À medida que revela em detalhes fatos que, na infância, formaram o núcleo duro do escritor, como se a pessoa que se apresentava aos leitores até então estivesse de certa maneira incompleta, Saramago nos descortina o primeiro grande personagem de sua obra, quiçá o fio condutor de sua vida real e de seus enredos fictícios, seu primeiro e maior crítico. Porquanto, nas palavras do autor, ao caminharmos mãos em mãos com aquela pequena versão de nós mesmos "talvez não cometêssemos certas deslealdades ou traições, porque a criança que nós fomos nos puxaria pela manga e diria: 'Não faças isso'" (SAramago, 2013, p. 37). Partindo de outro ponto de vista, também seria lícito afirmar que o autor apresenta o verdadeiro escritor de seus romances e de sua vida, a criança que o tempo todo esteve a lhe prevenir contra deslealdades ou traições, o pequeno mestre responsável por não permitir que esquecesse sua origem pobre e simples, a fonte sempiterna de imagens, sons, odores e sensações que iriam preencher sua obra. A esse respeito, o próprio autor indica várias impressões de sua infância que seriam reproduzidas em obras como Manual de pintura e caligrafia (1977), Memorial do convento (1982), O Evangelho segundo fesus Cristo (1991), Ensaio sobre a cegueira (1995) e Todos os nomes (1997), confirmando que memórias da infância, de fato, sempre estiveram presentes em seus escritos. 
A comprovação dessa hipótese talvez esteja evidente à entrada da obra, logo após a dedicatória. Definida como um posto avançado por Antoine Compagnon, a epígrafe é tanto símbolo da relação entre textos, quanto índice das leituras que precederam a presente. Mas é, também, acima de tudo "um ícone, no sentido de uma entrada privilegiada na enunciação" (COMPAGnon, 2007, p. 120). De maneira análoga à do crítico francês, Saramago considera as epígrafes "o melhor que às vezes os livros têm", servindo-lhes de "credencial e cartas de rumos." (SARAmAGo, 1997a, p. 458). Ademais, o autor troça: "quem não tiver paciência para ler os meus livros, passe os olhos ao menos pelas epígrafes porque por elas ficará a saber tudo" (SARAMAGO, 2009, p. 147). A brincadeira tem fundo de verdade: pórtico de seus romances, glosa de tudo o mais que há por vir, esses elementos paratextuais são, de maneira acentuada nos livros da fase da pedra, verdadeiras chaves de decifração do sentido da obra, cuidadosamente forjadas pelo autor na forma de ditos imaginários advindos de fontes igualmente irreais, como é o caso do "Livro dos conselhos" de onde haveria saído a sugestão que abre As pequenas memórias: "Deixa-te levar pela criança que foste".

Para Bachelard, a "criança é o poço do ser", no sentido de um arquétipo das emanações da alma (1988, p. 109). No exercício do devaneio voltado à infância, à medida que nos distanciamos do presente torna-se mais difícil discernir, entre as lembranças ditas e reditas, quais as contadas por nós mesmos, quais as ouvidas de outros. "Súmula de todo o incognoscível", a alma da criança agrega essas histórias, pessoas e valores em um modelo de vida primitiva à espera de ser redescoberto. Quando começou a tomar notas para o Livro das tentações, Saramago se assombra com a nitidez com que reconstitui "as palavras e os rostos, as paisagens e os ambientes, os nomes e os sons desse tempo longínquo" que foi sua infância e acrescenta que, no momento de registrar suas memórias:

casos e situações que, postos em movimento por uma potência memorizadora que me assombra por inesperada, se precipitam para mim como se irrompessem de um quarto escuro e fechado onde, antes, não tivessem podido reconhecer-se uns aos outros como passado de uma mesma pessoa, esta, e agora se descobrem, cada um deles, condição de outro, e, todos eles, de mim (SARAmago, 1994, p. 105).

Qual seja a abordagem teórica para refletir sobre a infância - "poço do ser", "verdade pessoal", "dobro de si" -, José Saramago responde com imagens análogas: "quarto escuro e fechado", "casulo mágico", "marca original", "berço". De uma maneira ou de outra, as muitas pistas distribuídas pelo autor em entrevistas, reportagens para a televisão, diários, crônicas e na longa trajetória de seus romances nos permitem entrever que o princípio da epígrafe de fato se aplica ao autor, como alguém que esteve o tempo todo a viver a escrita de si daquela criança de Azinhaga. Convém relembrar, ainda, que o projeto de autobiografia de José Saramago - surgido na década de 1980 - só pôde se concretizar quase 20 anos depois, 
em meio a um período marcado por uma dicção simplificada e pela busca da essência daquilo que nos faz humanos, traços recorrentes nos estudos sobre a infância. Desse modo, com sua biografia, Saramago logra entrelaçar literatura e memória na apresentação da criança que foi como mestre do adulto no qual se reconhecia. Essa conclusão nos é outorgada não somente pelo final da leitura de As pequenas memórias, mas sobretudo por uma extensa obra que esteve o tempo todo comunicando ao leitor que, ao contrário do que se poderia supor, a criança leva o homem pela mão e lhe escreve a história.

\section{Referências}

Aguilera, Fernando Gómez. José Saramago. A consistência dos sonhos - Cronobiografia. Lisboa: Caminho, 2008.

Aguilera, Fernando Gómez. As palavras de Saramago. São Paulo: Companhia das Letras, 2010.

Arias, Juan. José Saramago: o amor possível. Tradução de Rubia Prates Goldoni. Rio de Janeiro: Manati, 2003.

Arnaut, Ana Paula. José Saramago. Lisboa: Edições 70, 2008.

Bachelard, Gaston. A poética do devaneio. Tradução de Antonio Pádua Danesi. São Paulo: Martins Fontes, 1988.

Blanchot, Maurice. O livro por vir. Tradução de Leyla Perrone-Moisés. São Paulo: WMF Martins Fontes, 2013.

Compagnon, Antoine. O trabalho da citação. Tradução de Cleonice P. B. Mourão. Belo Horizonte: Editora da UFMG, 2007.

De Man, Paul. Autobiografia como des-figuração. Tradução de Joca Wolff. Sopro (Panfleto Político-Cultural), Florianópolis, n. 71, maio 2012. On-line. Disponível em: http://www.culturaebarbarie.org/sopro/outros/autobiografia.html.

Dosse, François. O desafio biográfico: escrever uma vida. Tradução de Gilson César Cardoso de Souza. São Paulo: Editora da USP, 2009.

Gusdorf, Georges. Condiciones y límites de la autobiografia. Anthropos: Boletín de información y documentación, Barcelona, n. 29, esp., p. 9-18, dez. 1991.

Lejeune, Philippe. O pacto autobiográfico: de Rousseau à internet. Tradução de Jovita Maria Gerheim Noronha. Belo Horizonte: Editora UFMG, 2008.

Marques, Carlos Vaz. José Saramago. In: Marques, Carlos Vaz. As palavras não se afogam ao atravessar o Atlântico. Rio de Janeiro: Tinta da China, 2015.

Mendes, Miguel Gonçalves. José e Pilar: conversas inéditas. São Paulo: Companhia das Letras, 2012. 
ReIs, Carlos. Diálogos com fosé Saramago. Lisboa: Caminho, 1998.

Saramago, José. Cadernos de Lanzarote. São Paulo: Companhia das Letras, 1997a.

Saramago, José. O autor como narrador. Revista Ler, n. 38, p. 36-41, 1997 b.

SARAmago, José. Cadernos de Lanzarote II. São Paulo: Companhia das Letras, 1999.

Saramago, José. As pequenas memórias. São Paulo: Companhia das Letras, 2006a.

SARAmago, José. "As pequenas memórias" - Entrevista. Visão: fornal de Letras, Lisboa, n. 937, 30 ago. 2006b.

Saramago, José. O caderno: textos escritos para o blog (setembro 2008 - março de 2009). São Paulo: Companhia das Letras, 2009.

Saramago, José. Deste mundo e do outro. Lisboa: Caminho, 2010.

Saramago, José. Discursos de Estocolmo. Lisboa: Fundação José Saramago, 2012.

Saramago, José. A estátua e a pedra. Lisboa: Fundação José Saramago, 2013.

Silva, João Céu e. Uma longa viagem com fosé Saramago. Lisboa: Porto, 2009.

Recebido em 16 de março de 2017.

Revisão em 22 de dezembro de 2017.

Aprovado em 14 de março de 2018.

\section{Resumo/Abstract/Resumen}

\section{A formação afetiva e literária de José Saramago em As pequenas memórias}

\section{Berttoni Licarião}

"Tudo é autobiografia", escreveu certo dia José Saramago. Tendo em vista o complexo edifício teórico que Saramago construiu para sua própria obra, buscamos compreender qual seria a contribuição daquele exercício memorialístico dentro de um conjunto ficcional já considerado e defendido pelo autor como expressão de si mesmo. Amparado por Gaston Bachelard, Philippe Lejeune, Georges Gusdorf e Paul de Man no que se refere à memória, à infância e à escrita autobiográfica, este artigo realiza uma leitura de As pequenas memórias como o "tempo de germinação" dos temas, enredos e personagens que se tornariam marca da ficção produzida pelo autor.

Palavras-chave: memória, infância, autobiografia, autoria, José Saramago. 
The affective and literary formation of José Saramago in Small memories

Berttoni Licarião José Saramago once wrote that "Everything is autobiography". Taking into account the complex theoretical scaffolding that the author built around his own work, this article attempts to assess what role Small memories plays within a fictional literary production which had already been regarded as the utmost expression of the persona of its author. Led by the writings of Gaston Bachelard, Philippe Lejeune, Georges Gusdorf and Paul de Man on memory, childhood and autobiographical writing, it delivers a reading of Small memories as the "germination time" of themes, plots and characters that would later become trademark of his novels.

Keywords: memory, childhood, autobiography, authorship, José Saramago.

\author{
The affective and literary formation of José Saramago in The small memo- \\ ries
}

\title{
Berttoni Licarião
}

\section{La formación afectiva y literaria de José Saramago en Las pequeñas me-} morias

\section{Berttoni Licarião}

"Todo es autobiografía", escribió cierto día José Saramago. Teniendo en cuenta el complejo edificio teórico que Saramago construyó en su propia obra, buscamos comprender cuál sería la contribución de Las pequeñas memorias dentro de un conjunto ficcional ya considerado y defendido por el autor como expresión de sí mismo. Basado en consideraciones de Gastón Bachelard, Philippe Lejeune, Georges Gusdorf y Paul de Man sobre la memoria, la infancia y la escritura autobiográfica, este artículo realiza una lectura de Las pequeñas memorias como el "tiempo de germinación" de los temas, tramas y personajes que se convertirían en una marca de la ficción producida por Saramago.

Palabras clave: memoria, infancia, autobiografía, autoría, José Saramago. 